Filip Cyuńczyk

Uniwersytet w Białymstoku e-mail: filip.cyunczyk@gmail.com

telefon: +48 857457153

DOI: 10.15290/mhi.2015.14.01.05

\title{
Dylematy wokół zagadnienia rządów prawa w potranzycyjnej Czechosłowacji (Rep. Czeskiej) i na Węgrzech - analiza przypadków
}

\author{
SUMMARY \\ Dilemmas of Rule of Law in Post-transitional Czechoslovakia (Czech Rep.) \\ and Hungary - Case Study
}

The main task of this text is to present some general statements and discussions related to the rule of law dilemmas in relation to dealing with past processes in post-transitional Czechoslovakia (now the Czech Republic) and Hungary. One of the main challenges is to answer the question of how deeply disputes were rooted in national memory relating to communist contempt for the law and how influential was the fear of suspicion that dealing with the past in the post-communist era just represents some kind of political revenge.

Key words: Czechoslovakia, Hungary, dealing with the past, de-communisation, rule of law after communism

Słowa kluczowe: Czechosłowacja, Węgry, dekomunizacja, rozliczenie z przeszłością

\section{Wstęp}

Profesor A. Lityński, w swoich pracach dotyczących prawa sowieckiego, wielokrotnie zwracał uwagę na dość swobodny stosunek bolszewików do takich problemów jak zasady praworządności czy pewności prawa. Podkreślał także ideologiczne podporządkowanie prawa ówczesnym władcom Rosji i ich idee fix eksportu światowej rewolucji proletariatu. Wszystko to razem składało się na dość ponury obraz leninowskiej pogardy dla prawa trwającej, oczywiście z różnym natężeniem, de facto do upadku systemu na przełomie lat osiemdziesiątych i dziewięćdziesiątych.

Sam upadek komunizmu w Europie Środkowej i Wschodniej poprzedziły inne przejścia do demokracji na Półwyspie Iberyjskim i w Ameryce Połu- 
dniowej. Niemal równocześnie rozpoczął się proces wychodzenia z apartheidu w Republice Południowej Afryki. Wielu spośród badaczy tej tematyki ma tendencje do stosowania tej samej bazy porównawczej zarówno dla przywołanych Hiszpanii i Portugalii, Ameryki Południowej, jak i Europy Środkowo-Wschodniej. Jest to dość ciekawe jednak z góry skazane na porażkę. Przede wszystkim autorzy nie uwzględniają historii omawianych społeczeństw przed nastaniem systemów niedemokratycznych. W swoich wnioskach bardzo często szukają przyczyny takiego stanu rzeczy w narracjach politycznych i publicystyce. C. Gonzalez-Enriquez w podrozdziale poświęconym dekomunizacji w Polsce wprost starała się połączyć stosunek premiera T. Mazowieckiego do kwestii obcowania z przeszłością z jego członkostwem w stowarzyszeniu PAX ${ }^{1}$. Wydarzenia związane z lustracją, osądzenia sprawców przestępstw politycznych czy mordów sądowych są przez nich opisywane bardzo często z pominięciem kontekstu lokalnego. Ponadto, sama droga przejścia państw Europy Środkowo-Wschodniej od systemów niedemokratycznych do demokracji była różna - od Państw Bałtyckich, które całkowicie wyrzekły się spuścizny Republik Radzieckich, uznając je za byty obce i narzucone, przez drogę właściwą m.in. dla Polski, Czechosłowacji czy Węgier, polegającą na negocjacjach pomiędzy dotychczasową władzą a opozycją, które stworzyły ramy dla procesów przemian ustrojowych i gospodarczych aż po całkowitą likwidację państwa i jego porządku prawnego, jak miało to miejsce w przypadku Niemieckiej Republiki Demokratycznej.

Jednym ze skutków upadku komunizmu była bardzo ożywiona dyskusja nad kierunkami reformy prawa. Zadawano sobie pytania, jak ma ono wyglądać? Jakim zasadom powinno hołdować? Przede wszystkim zgadzano się co do jednego - systemy prawne nowych demokracji powinny silnie chronić uprawnienia podmiotowe. W praktyce sprowadzono to do sytuacji, że treść nowych aktów prawnych powinna stać w zdecydowanej opozycji do dotychczasowego prawa "socjalistycznego". Doszło więc do dość silnego zderzenia dwóch punktów widzenia. Ustawodawcy w państwach Europy Środkowo-Wschodniej musieli zmierzyć się z oczekiwaniami części społeczeństw żądających osądzenia i rozliczenia przeszłości. Z drugiej zaś strony, musieli tworzyć akty prawne oparte na zasadach rządów prawa. $\mathrm{W}$ ten sposób starali się pokazać, że nowe ustawodawstwo nie ma nic wspólnego z rewanżyzmem. Stworzyło to dość ciekawą sytuację zarówno dla socjologów, jak i obecnie dla historyków prawa. Okres ten został naznaczony przede wszystkim dążeniem do bezkrwawej zmiany reżimu. Jednocześnie część sił politycznych dążyła do pojednania i zjednoczenia społeczeństw państw postkomunistycznych. Dyskusje toczyły

1 C. Gonzalez-Enriquez, Decomunization and Political Justice in Central and Eastern Europe, [w:] The Politics of Memory. Transitional Justice in Democratizing Societies, red. A. Barahona de Brito, C. Gonzalez-Enriquez, P. Aguilar, New York 2001, s. 238. 
się też wokół pamięci o niedawnej przeszłości. Stąd z kolei wynikały spory prawne dotyczące palących kwestii szeroko rozumianego obcowania z przeszłością, które musiały rozstrzygać sądy najwyższe i konstytucyjne, prezentując przy tym diametralnie różne spojrzenie na problematykę rządów prawa i gwarancji konstytucyjnych. To z kolei rodzi pytanie, które może zainteresować badaczy procesów społecznych - skąd wynikały takie rozbieżności? Czy ich początkiem nie była właśnie, tak często podkreślana przez A. Lityńskiego, bolszewicka pogarda dla prawa i jego podstawowych zasad? Czy formalistyczne podejście do problemów prawnych po przejściu ustrojowym nie wynikało $\mathrm{z}$ obawy przed oskarżeniami o brak jakichkolwiek różnic między „demokratami” i „komunistami”? Również takimi, które sugerowały, że cała legislacja dotycząca prób rozwiązania problemów z przeszłości jest zwyczajnym rewanżem na przedstawicielach dotychczasowych władz i innych grup uważanych za uprzywilejowane przez poprzedni system. Dość istotny wkład do dyskusji wniosły orzeczenia Sądów Konstytucyjnych Węgier i Czechosłowacji (po 1 stycznia 1993 - Republiki Czeskiej). Ich analiza umożliwia dokładne ukazanie argumentów obu stron sporu o przeszłość.

\section{Węgry i Czechosłowacja}

Trudno nie zauważyć podobieństw w historii obu państw. W Czechosłowacji komuniści zdobyli władzę wskutek zamachu stanu na początku 1948 r., który następnie nazwali „zwycięskim lutym”. W przypadku Węgier droga do ustanowienia „władzy ludowej" była bardzo podobna do metod użytych w Polsce. Prowadziła od szerokiej koalicji ,jedności narodu", przez zawłaszczenie kolejnych dziedzin i obszarów funkcjonowania państwa, do ostatecznego wyeliminowania niepożądanych koalicjantów i skupienia całej władzy w swoich rękach. Pod koniec lat osiemdziesiątych sytuacja wewnętrzna na Węgrzech i w Czechosłowacji była bardzo podobna. Liderzy państw przywiezieni na sowieckich czołgach w trakcie interwencji w roku 1956 (Węgry) i 1968 (Czechosłowacja) wciąż byli u władzy. Ponadto, zarówno na Węgrzech, jak i w Czechosłowacji $\mathrm{w}$ trakcie transformacji ustrojowej ujawnił się dość istotny paradoks. Mimo faktu, że oba państwa bardzo mocno doświadczyły sowieckiej przemocy, pierwsze wybory parlamentarne pozwoliły utrzymać się $\mathrm{w}$ parlamencie formacjom politycznym bezpośrednio związanym z dotychczasowymi reżimami. Oznaczało to, że pewna część społeczeństwa - na Węgrzech Węgierska Partia Socjalistyczna otrzymała 10,5\% głosów - mimo ewidentnego bankructwa systemu, dalej utożsamiała się z jego przedstawicielami. Oczywisty był fakt, że część tego poparcia pochodziła od osób związanych z reżimem. Nie można jednak zapomnieć, że zarówno G. Husak jak i J. Kadar w celu uspokojenia nastrojów społecznych po radzieckich interwencjach zbrojnych w ich państwach, pro- 
wadzili politykę, którą można streścić słowami - żadnej wolności w zamian za relatywnie wysoki poziom życia. Taki stan rzeczy z pewnością również pomógł formacjom postkomunistycznym w pierwszych wyborach do parlamentów.

Po 1990 Węgry i Czechosłowacja stanęły przed problemem typowym dla wszystkich państw po transformacji ustrojowej. Musiały ustosunkować się do pytania - w jaki sposób należy obcować $\mathrm{z}$ dotychczasową, trudną przeszłością? Jak już wspomniałem we wstępie, odpowiedź na to pytanie była dość skomplikowana z kilku powodów. Przede wszystkim, istotnym elementem przejścia ustrojowego, nie tylko w Czechosłowacji i na Węgrzech, były zmiany lub bardzo istotne nowelizacje dotychczasowych konstytucji. Ich celem było jak najszybsze zagwarantowanie szerokiego katalogu praw i wolności obywatelskich opartych na rządach prawa. Generalnie, głównym problemem w relacji między zagadnieniem obcowania z przeszłością a rządami prawa była odpowiedź na pytanie, czy one w jakikolwiek sposób ze sobą korespondują i czy da się je powiązać? Tietel $\mathrm{w}$ jednej ze swoich prac na temat sprawiedliwości tranzycyjnej podkreśliła także inny problem - „czy istnieje jakakolwiek teoria odpowiedzialności, która pozwala na przejście z represyjnego do bardziej liberalnego reżimu" ${ }^{\prime 2}$.

Sędziowie zarówno węgierskiego, jak i czechosłowackiego/czeskiego Trybunału Konstytucyjnego musieli zmierzyć się przede wszystkim z zagadnieniem określenia warunków prawnych przejścia ustrojowego. Zwłaszcza w sytuacji, którą L. Sólyom określił mianem „nadzwyczajnych okoliczności”3. W celu ich zdefiniowania i określenia, czy w ogóle mogą mieć zastosowanie postawił następujące pytanie - „Czy jakiekolwiek wydarzenia historyczne mogą prowadzić do zawieszenia pewnych gwarancji konstytucyjnych? W skrócie czy może istnieć konstytucjonalizm tranzycyjny inny od normalnego" ${ }^{4}$. W swoim tekście podkreślił też inne problemy, z jakimi musieli zmierzyć się sędziowie. Były to m.in. uchwalenie aktów karnych, w których prawo miałby działać wstecz ${ }^{5}$. Ponadto, mieli zmierzyć się z kwestią restytucji mienia i lustracji ${ }^{6}$. Musieli także określić moment zakończenia "okresu tranzycyjnego" (stymulującego nadzwyczajne okoliczności działania organów państwa) i jego wpływ na stabilizację państwa ${ }^{7}$. Generalnie, uchwalenie aktów prawnych dotyczących wyżej wymienionych zagadnień miało łączyć się bezpośrednio z „nadzwyczajnymi okolicznościami" okresu przejścia ustrojowego. Sędziowie musieli zmierzyć się także

2 R. Tietel, Transitional Rule of Law, [w:] Rethinking the rule of law after the communism, red. A. Czarnota, M. Krygier, W. Sadurski, Budapest, New York 2005, s. 282.

3 L. Sólyom, Role of Constitutional Courts in the Transition to Democracy, "International Sociology" 2003, t. 18, nr 1, s. 137.

4 Ibidem.

5 Ibidem, s. 140.

6 Ibidem, s. 141.

7 Ibidem. 
jeszcze z jednym zagadnieniem. Chodziło o kwestie zdefiniowania, czym są owe „nadzwyczajne okoliczności” i wywiedzenie właśnie z definicji kiedy i jakich sytuacjach oparte na nich działanie byłoby usprawiedliwione.

W celu rozwikłania przytoczonych problemów węgierski Sąd Konstytucyjny stworzył koncepcję, którą L. Sólyom określił mianem „rewolucji pod rządami prawa"8. Był to wybór pomiędzy „podstawowymi zasadami sprawiedliwości a pozytywnym prawem konstytucyjnym" ${ }^{\prime \prime}$. W swoich orzeczeniach sędziowie podkreślali, że jak najbardziej rozumieją rewolucyjność zmian, jakie przechodziły Węgry $\mathrm{w}$ tamtym czasie. Poza tym, doskonale zdawali sobie sprawę z faktu, że uchwalona nowelizacja Konstytucji, która praktycznie spowodowała zmianę jej treści, jest prawno-pozytywnym elementem przebudowy społeczeństwa. Przyznali też, że nowelizacja wprowadził nowy porządek prawny. Jednakże podkreślili również, że każda nowa ustawa powinna być zgodna z Konstytucją. Wprost uznali, że niemożliwe jest podważenie podstawowej hierarchii aktów prawnych. Sólyom podsumował to stwierdzeniem, że „państwo pod rządami prawa nie może tworzyć niczego co by je podważało"10. Węgierski Trybunał Konstytucyjny zastosował tę logikę do rozwiązania wszelkich niejasności związanych z problematyką wskazaną przez L. Sólyoma. Prymat zasad państwa prawa i demokracji liberalnej miał być brany pod uwagę np. w przypadku prób osądzenia funkcjonariuszy węgierskiej służby bezpieczeństwa, nawet jeśli z moralnego punktu widzenia postawienie ich $\mathrm{w}$ stan oskarżenia i osądzenie było czymś oczywistym. Sam Sólyom zastosował opisane zaplecze teoretyczne, gdy orzekał, wraz z A. Szabo, o konstytucyjności ustawy o odpowiedzialności karnej byłych funkcjonariuszy służb bezpieczeństwa, w której przewidziano działanie prawa również $\mathrm{z}$ mocą wsteczną ${ }^{11}$.

W Czechosłowacji, a od 1 stycznia 1993 r. Republice Czeskiej, mimo nakreślonych już podobieństw historycznych, praktyka orzecznicza podążyła zgoła inną drogą. Już od 1990 Czesi rozpoczęli proces uchwalania aktów prawnych, które miały zagwarantować szybką dekomunizację, lustrację, restytucję mienia i rehabilitację osób poszkodowanych przez system komunistyczny. Wszystkie ustawy wpisywały się w nakreślone przez L. Sólyoma "nadzwyczajne okoliczności" związane z przejściem ustrojowym. Do 1992 r. zostały uchwalone następujące akty prawne: o sądowej rehabilitacji12, o złagodzeniu konsekwencji

8 Ibidem, s. 138.

9 Ibidem.

10 Ibidem.

11 Zob. Wyrok Trybunału Konstytucyjnego Republiki Węgierskiej z 3.03.1992, sygn. akt 11/1992. (III. 5.) AB határozat, http://public.mkab.hu/dev/dontesek.nsf/0/A0D36B21A86C45BEC1257AD A0052B4F7?OpenDocument

12 Zakon c 119/1990 sb. 
naruszeń prawa własności ${ }^{13}$, o cofnięciu prawa długoterminowego użytkowania nieruchomości będących własnością skarbu państwa przez Komunistyczną Partię Czechosłowacji14, o powrocie majątku Komunistycznej Partii Czechosłowacji we władanie obywateli Czeskiej i Słowackiej Republiki Federalnej ${ }^{15}$, o pozasądowej rehabilitacji16 i wreszcie tzw. Duże Prawo Lustracyjne, czyli ustawę o dodatkowych warunkach piastowania funkcji w urzędach i organizacjach państwowych Czeskiej i Słowackiej Republiki Federalnej, Republice Czeskiej i Republice Słowackiej ${ }^{17}$. Interesująca była przede wszystkim sekwencja uchwalania poszczególnych aktów prawnych. Należy również nadmienić, że po rozpadzie Czechosłowacji ustawa lustracyjna pozostała w mocy tylko na terenie Republiki Czeskiej. Słowacy nie zaadaptowali jej do swojego systemu prawnego. Czechosłowacka, a następnie już tylko czeska, legislatura zdecydowała się uchwalać poszczególne ustawy według pewnego rodzaju hierarchii potrzeb. Za najpilniejszą sprawą uznali przywrócenie godności ofiarom systemu, w związku w tym niezwłocznie uchwalili ustawą rehabilitacyjną. Następnie parlament zdecydował się na uregulowanie kwestii prawa własności. Całą zaś klamrę „ustawodawstwa nadzwyczajnych okoliczności” zamknęła ustawa lustracyjna; ta sama, która została znacznie okrojona na Węgrzech ze względu na jej sprzeczność z literalnymi założeniami podstawowych zasad rządów prawa. Z chronologii procesu ustawodawczego można wywnioskować, że wszystkie działania miały na celu stworzenie jak najszerszego zaplecza i poparcia społecznego dla procesów przemian. Wszystkie uchwalone ustawy były też, podążając za wywodami L. Sólyoma, „oczywiste z moralnego punktu widzenia”. Czesi zrezygnowali z formalizmu na rzecz zaspokojenia oczekiwań społecznych. Do dziś wielkie kontrowersje wśród badaczy tematu wywołuje orzeczenie Trybunału Konstytucyjnego Republiki Czeskiej stwierdzające konstytucyjność „Ustawy o bezprawności reżimu komunistycznego i oporze przeciwko niemu"18. Dla wielu z nich było ono właśnie naruszeniem podstawowych zasad rządów prawa. Uitz napisała wprost, że wówczas „zasada rządów prawa ucierpiała w stopniu znacznym"19. Czeski Trybunał, w swoim orzeczeniu ${ }^{20}$, stanął na stanowisku, że "stary" i "nowy" reżim nie są ze sobą w żaden sposób związane. Takie stwierdzenie mogło rodzić pytania, co w związku z tym

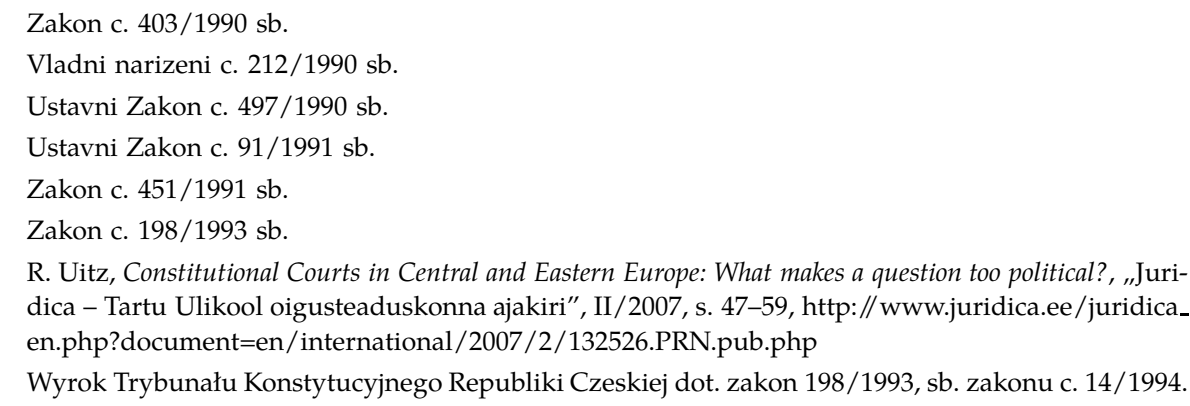
dica - Tartu Ulikool oigusteaduskonna ajakiri", II/2007, s. 47-59, http://www.juridica.ee/juridica. en.php?document=en/international/2007/2/132526.PRN.pub.php

Wyrok Trybunału Konstytucyjnego Republiki Czeskiej dot. zakon 198/1993, sb. zakonu c. 14/1994. 
należało zrobić z całym dotychczasowym porządkiem prawnym? Czy wciąż obowiązywały kodeksy i ustawy uchwalone w okresie komunizmu? Według sędziów - oczywiście, że wciąż obowiązywały. Jednakże według nich, w przeciwieństwie do stanowiska węgierskiego, w społeczeństwie istnieją także inne niż tylko prawno-pozytywne systemy normatywne. Zalecali oni szersze spojrzenie na tę problematykę. Uitz $\mathrm{w}$ przytaczanym już tekście $\mathrm{w}$ następujący sposób zaprezentowała sposób myślenia sędziów Trybunału Konstytucyjnego Republiki Czeskiej - „Prawo pozytywne, jakkolwiek, nie przywiązuje się jedynie do formalnej legalności, raczej interpretacja i aplikacja norm prawnych są podporządkowane ich podstawowemu celowi, prawo jest kwalifikowane przez szacunek do podstawowych wartości społeczeństwa żyjącego w systemie demokratycznym i środków wprowadzania tych wartości poprzez normy prawne. Oznacza to, że nawet mimo formalnej kontynuacji "starego" porządku prawnego nie ma mowy o jakiejkolwiek kontynuacji „starego reżimu” z punktu widzenia podstawowych wartości"21.

\section{Dylematy zagadnienia rządów prawa}

W zaprezentowanych w poprzednim podrozdziale opiniach i stanach faktycznych przewijał się jeden wspólny element. Było to generalne spojrzenie na prawo i jego rolę $\mathrm{w}$ procesie przejścia ustrojowego. $\mathrm{Z}$ jednej strony ukształtowały się poglądy bliskie linii orzeczniczej węgierskiego Sądu Konstytucyjnego i poglądom chociażby cytowanej w niniejszej pracy R. Uitz. W opozycji zaś do „węgierskiego punktu widzenia" na temat rządów prawa ulokowały się poglądy legislatury czeskiej. $\mathrm{W}$ istotnych sprawach były one wspierane przez linię orzeczniczą tamtejszego Trybunału Konstytucyjnego. W tym miejscu warto nadmienić, że poglądy i linia argumentacji Trybunałów z Czech i Węgier były wykorzystywane przez sądownictwo konstytucyjne pozostałych państw postkomunistycznych w Europie Środkowej i Wschodniej. Z jednej strony sędziowie zaprezentowali stricte formalistyczne podejście do problematyki rządów prawa, z drugiej zaś starali się uwzględnić takie kwestie, jak wartości uniwersalne, moralność czy oczekiwania społeczeństwa. Uwzględnienie ich mogło z kolei powodować konflikt pomiędzy nimi a normami prawa stanowionego.

$Z$ reguły większość argumentów zwolenników radykalnego, formalistycznego podejścia do kwestii rządów prawa były zbieżne z tzw. „negatywnymi koncepcjami rządów prawa". Wówczas jego główną rolą miała by być ochrona obywateli przed wszelkiej maści nadużyciami ze strony rządzących. Sólyom, Uitz oraz inni badacze i sędziowie, którzy prezentowali „węgier-

21 R. Uitz, op. cit. 
ski punkt widzenia" widzieli rządy prawa w kontekście nakreślonym w latach siedemdziesiątych przez Raza. Stwierdził on wówczas, że są one procedurą „rządów poprzez prawo, nie przez człowieka (ang. goverment by law, not by man)"22. W kontekście procesów rozliczeń z przeszłością, nie tylko na Węgrzech i w Czechosłowacji (Czechach), ale na całym obszarze postsowieckim, dawało ono szansę na storpedowanie planów chociażby lustracji przez jej przeciwników. Nowo ukonstytuowanym władzom wywodzącym się z opozycji chodziło też o ukazanie widocznych różnic między „nowymi” demokratami a „dawnymi" przedstawicielami reżimu. Niezależnie, czy były to Węgry, Czechosłowacja, czy Polska, ich ówczesne stanowisko najdosadniej ukazywały słowa B. Geremka. W wywiadzie udzielonym A. Michnikowi 16 września 1993 roku i opublikowanym w "Gazecie Wyborczej” wypowiedział się na temat lustracji. Zapytany przez ówczesnego redaktora naczelnego o swoje poglądy na ten temat powiedział: „Ustawę lustracyjną uważam za zło konieczne - w tym sensie konieczne, że przecież nie można żyć $\mathrm{z}$ trupem w szafie. Lepiej go usunąć. Od tego raczej nie uciekniemy. Mam wątpliwości, na ile będzie to wykonalne" ${ }^{23}$. W dalszej części wywiadu mówił też o dylematach rewolucjonistów: „Próbowałem ją promować (lustrację - dop. F.C.), ale zostałem przekonany, że nie da się lustracji przeprowadzić w ludzki sposób. Zostało mi przekonanie, że niepodjęcie działań $w$ tej sprawie jest równie złe jak ich podjęcie. Wiem, że dla rewolucjonistów, którzy pragną oddzielić 'stare' od 'nowego' dylematem bywa wybór co wybrać gilotynę czy latarnię dla celów nieoświetleniowych. Nie jest to mój dylemat"24. Nie był to pogląd odosobniony. Halmai i Scheppele w swoim tekście Living Well is The Best Revenge $e^{25}$ byli bardzo bliscy poglądom B. Geremka przedstawionym w cytowanym wywiadzie. O metodach obcowania z przeszłością użytych w Czechosłowacji, a później w Republice Czeskiej pisali o jako „bardziej karnych"26 i stojących w kontraście do rozwiązań przyjętych na Węgrzech. O co właściwie chodziło przeciwnikom lustracji i innych elementów procesów obcowania z przeszłością? Ogólnie ich postawy nie zostały stworzone przeciwko tym konkretnym postulatom. Jak już wspomniałem, ich głównym celem było ukazanie zasadniczych różnic pomiędzy dotychczasowym, niedemokratycznym, reżimem i nową jakością, jaką oni mieliby wnieść do życia politycznego i społecznego państw Europy Środkowej i Wschodniej. Właśnie J. Raz, The Rule of Law and Its
University Press, 1979, s. 212. http://wyborcza.pl/1,75248,138405.html. Ibidem.

Zob. G. Halmai, Scheppele K., Living Well is the Best Revenge - The Hungarian Approach to Judging the Past, [w:] Transitional Justice and the Rule of Law in New Democracies, Notre Dame and London 1997. Ibidem, s. 179. 
społeczeństwo miało być głównym punktem odniesienia w tej debacie. Wielu badaczy zmiany ustrojowej w naszej części świata odnosi się także do modelu tranzycji użytego $\mathrm{w}$ poszczególnych państwach. Pisali o tym m.in. przywołani wcześniej G. Halmai i K. L. Scheppele. W cytowanym już tekście połączyli oni łagodny kurs rządu węgierskiego $\mathrm{w}$ stosunku do problemu obcowania $\mathrm{z}$ przeszłością z "przekazaniem władzy w drodze negocjacji” ${ }^{27}$. Ten tekst nie jest ani właściwym miejscem, ani nie jest jego rolą dogłębna analiza modeli tranzycyjnych i ich relacji do sposobu rozliczeń z przeszłością. W przypadku dylematów dotyczących zagadnienia rządów prawa mogło przede wszystkim chodzić o ukazanie ogromnej różnicy między porządkiem prawnym i szacunkiem do prawa $\mathrm{w}$ nowych demokracjach a komunistycznym bezprawiem. Przedstawiciele nowej władzy argumentowali, że nawet jeśli pewne sytuacje są oczywiste z moralnego punktu widzenia (L. Sólyom), to osądzanie sprawców przy użyciu metod polegających na naginaniu i swobodnej interpretacji przepisów prawa nie może mieć miejsca. Stwierdzili oni bowiem, że wówczas nie będzie się niczym różniło od sowieckiej pogardy dla prawa.

Zwolennicy czeskiego sposobu obcowania z przeszłością w swojej argumentacji powoływali się na przyjętą przez Trybunał Konstytucyjny Republiki Czeskiej zasadę częściowej lub moralnej dyskontynuacji. Czesi nie odrzucili, w przeciwieństwie do Państw Bałtyckich, całkowicie swojej komunistycznej przeszłości. Nie uznali tego okresu za czas okupacji. Po rozpadzie Czechosłowacji 1 stycznia 1993 r. Republika Czeska przejęła wszelkie zobowiązania prawnomiędzynarodowe. Jednak czescy prawnicy dokonali pewnego formalnego zdystansowania się od reżimu komunistycznego. Podniesiono, że komuniści zdobyli władzą w wyniku zamachu stanu, nie posiadali jakiejkolwiek legitymacji społecznej, a także ich władza zachowała się tylko dzięki interwencji zbrojnej państw należących do Układu Warszawskiego. W rezultacie przez ową negację dotychczasowego porządku z moralnego punktu widzenia Trybunał Konstytucyjny Republiki Czeskiej dokonał legitymizacji procesów obcowania z przeszłością. W przeciwieństwie do węgierskiej drogi orzeczniczej dla Czechów rządy prawa nie były ani narzędziem, ani formalistycznym kneblem. Wprowadzenie zasady rządów prawa zostało potraktowane jako immanentna część nowego porządku odrzucona przez przedstawicieli poprzedniego systemu. Przyjęto, że społeczeństwo, które poniosło choć jedną ofiarę z ręki reżimu, ma prawo oczekiwać zastosowania nadzwyczajnych środków w celu naprawienia niesprawiedliwości. Przyjęto także, że okresy przejściowe, rewolucyjne i inne z samej swojej natury nie mogą być jasno określone i zamknięte w cenzurze czasowej. W Republice Czeskiej dokonał się proces, który można nazwać implementacją zasad sprawiedliwości tranzycyjnej w duchu, 
a nie $\mathrm{w}$ sztywnych formalnych ramach rządów prawa. Proces legislacyjny od samego początku prowadzono z szacunkiem i w odniesieniu również do wartości, a nie tylko w ramach kelsenowskiej czystej teorii norm.

\section{Uwagi i wnioski}

Mimo że przedstawione $\mathrm{w}$ niniejszym tekście rozważania i dylematy dotyczące rządów prawa na obszarze postsowieckim w Europie Środkowej i Wschodniej miały miejsce dwadzieścia pięć lat temu, to jednak wciąż pozostają aktualne. Najlepszym tego przykładem mogą być dyskusje toczące się obecnie na Ukrainie. W 2014 r. ukraiński parlament - Rada Najwyższa $\mathrm{w}$ pierwszym czytaniu uchwalił ustawą lustracyjną ${ }^{28}$. Zastosowano w niej dość radykalne i kontrowersyjne rozwiązania. Komitet Lustracyjny pod przewodnictwem J. Soboleva zdecydował się pójść radykalną drogą w celu jak najszybszego oczyszczenia elit. Ustawa jest problematyczna w kilku punktach, przede wszystkim dotyczących samej procedury, jak i w kontekście katalogu podmiotów podlegających lustracji. W dniach 12 i 13 grudnia 2014 r. Komisja Wenecka przedstawiła stronie ukraińskiej swoje uwagi do tego aktu prawnego ${ }^{29}$; główne były bardzo zbliżone do dylematów dotyczących rządów prawa, jakie zaprezentował w swoim tekście L. Sólyom.

Podsumowując, można stwierdzić, że spór pomiędzy dwoma spojrzeniami na rządy prawa $w$ kontekście rozliczeń z przeszłością jest właściwy dla niemal wszystkich państw postkomunistycznych. Bardzo wiele do tej dyskusji wniosły także orzeczenia Trybunałów Konstytucyjnych Polski i Rumunii, które również wyrażały swoje opinie na temat ustaw lustracyjnych $w$ tych państwach. Argumenty obu stron sporu są dość poważne i głęboko ulokowane w społecznych pamięciach zbiorowych społeczeństw postkomunistycznych. W momencie przejścia ustrojowego obraz komunistycznego nihilizmu prawnego, swobodnej, ideologicznej interpretacji przepisów prawa, de facto bezprawia, był wśród nich bardzo silny i świeży. Nic więc dziwnego, że umiarkowane grupy wywodzące się z kręgów opozycyjnych obawiały się oskarżeń o chęć rewanżu i porównywania ich $z$ dotychczasowymi oprawcami. Jednakże, jak starał się argumentować czeski Sąd Konstytucyjny, a co jest istotne dla badaczy z zakresu nauk społecznych i socjologii prawa, społeczeństwa nie da się zorganizować jedynie na podstawie norm prawa stanowionego. Zawsze będą dochodzić

Zob. Law on Government Cleansing (tekst anglojęzyczny), sygn. Rady Europy CDL-REF (2014)046, http://www.venice.coe.int/webforms/documents/?pdf=CDL-REF\%282014\%29046-e.

29

Zob. Interim opinion one the Law on Government Cleansing (tekst anglojęzyczny), sygn. Rady Europy CDL-AD (2014)044, http://www.venice.coe.int/webforms/documents/?pdf=CDL-AD\%28 2014\%29044-e. 
w nim do głosu pewne wartości ogólne i w tym kontekście warto się zastanowić, czy formalne ramy rządów prawa mogą stać w sprzeczności do poczucia sprawiedliwości? Profesor A. Lityński w swoich pracach dotyczących Związku Radzieckiego zawsze podkreślał obudowę ideologiczną towarzyszącą tworzeniu prawa komunistycznego. Wydaje się, że gdyby nie eksperyment społeczny, który rozpoczął się wraz z przewrotem bolszewickim w dzisiejszej Rosji, niniejszy tekst nie miał by racji bytu. Prawnicy, socjologowie i socjologowie prawa nie musieliby szukać źródeł pewnych postaw i poglądów. Jednak skoro już do tego doszło, a dyskusje wokół poruszonych zagadnień, gdy przygasną w jednym kraju pojawiają się w innym, warto zastanowić się jak głęboko, tak często podkreślana przez prof. A. Lityńskiego, sowiecka pogarda dla prawa wryła się w świadomość społeczeństw w państwach postkomunistycznych.

\section{Bibliografia}

Geremek B., Geremek B. rozmowa z Adamem Michnikiem, „Gazeta Wyborcza” z 16 września $1993 \mathrm{r}$.

Gonzalez-Enriquez C., Decomunization and Political Justice in Central and Eastern Europe, [w:] The Politics of Memory. Transitional Justice in Democratizing Societies, red. Aguilar P., Barahona de Brito A., Gonzalez-Enriquez C., New York 2001.

Halmai G., Scheppele K., Living Well is the Best Revenge - The Hungarian Approach to Judging the Past, [w:] Transitional Justice and the Rule of Law in New Democracies, Notre Dame and London 1997.

Raz J., The Rule of Law and Its Virtue, [w:] The Authority of Law, Essays on Law and Morality, Oxford University Press, 1979.

Sólyom L., Role of Constitutional Courts in the Transition to Democracy, "International Sociology" 2013, t. 18, nr 1.

Tietel R., Transitional Rule of Law, [w:] Rethinking the rule of law after the communism, red. A. Czarnota, M. Krygier, W. Sadurski, Budapest, New York 2005.

Uitz R., Constitutional Courts in Central and Eastern Europe: What makes a question too political?, „Juridica - Tartu Ulikool oigusteaduskonna ajakiri” 2007, nr II. 